\title{
Faktor-Faktor yang Mempengaruhi Status Gizi Balita di Nagari Abai Siat Wilayah Kerja Puskesmas Koto Besar Kabupaten Dharmasraya
}

\author{
Yuliani $^{a}$, Deswita ${ }^{a}$ \\ ${ }^{a}$ Fakultas Keperawatan Universitas Andalas \\ Email : yuliani_arsyad@yahoo.com
}

\begin{abstract}
A period of child under five year referred as with a period is golden. This matter is caused by child of child under five year represent group showing fast growth. Pursuant to the mentioned hence very needed by is optimal attention to status of gizi child at that moment. Status of Gizi can influence by pattern eat, disease of infection, knowledge of mother, economic status, culture, service of health, food production and hygiene of environment. Target of this research that is to know factors influencing status of gizi child under five year as for the factors that is: pattern eat, disease of infection, mount knowledge of mother, economic status, service of culture and health. This Research type is analytic with approach of study sectional cross. This research use technique of proporsional sampling random by 196 responder that is mothers of child under five year. Data collection was conducted from 1-20 April 2013. Data collection using questionnaires from each variable entirely there are 28 question. Result of research show there are relation which is signifikan $(p=0,000)$ among pattern eat, level knowledge of mother, disease of infection, economic status and cultural with status of gizi balita. Result of this research suggest to mothers of balita to be ever improve its knowledge about gizi to and family of child under five year through various media and also by following counselling of health and to officer of health to be continuing to improve performance in overcoming problems of health especially the problem of child under five year gizi.
\end{abstract}

Keywords: factors influencing, status of gizi, balita.

Masa balita disebut dengan masa keemasan.Hal ini disebabkan karena anak balita merupakan kelompok yang menunjukkan pertumbuhan yang pesat.Berdasarkan hal tersebut maka sangat diperlukan perhatian yang optimal terhadap status gizi anak pada saat itu.Status gizi dapat dipengaruhi oleh pola makan, penyakit infeksi, pengetahuan ibu, status ekonomi, budaya, pelayanan kesehatan, produksi pangan dan kebersihan lingkungan. Tujuan penelitian ini yaitu untuk mengetahui faktor-faktor yang mempengaruhi status gizi balita adapun faktor-faktor tersebut yaitu: pola makan, penyakit infeksi, tingkat pengetahuan ibu, status ekonomi, pelayanan kesehatan dan budaya. Jenis penelitian ini adalah analitik dengan pendekatan cross sectional study.Penelitianini menggunakan teknik proporsional random sampling dengan 196 responden yaitu ibu-ibu balita.Pengumpulan data dilakukan dari tanggal 1-20 April 2013.Pengumpulan data menggunakan kusioner dari masing-masing variabel dengan seluruhnya terdapat 28 pertanyaan. Hasil penelitian menunjukkan terdapat hubungan yang signifikan $(\mathrm{p}=0,000)$ antara pola makan, tingkat pengetahuan ibu, penyakit infeksi, status ekonomi dan budaya dengan status gizi balita. Hasil penelitian ini menyarankan kepada ibu-ibu balita agar senantiasa meningkatkan pengetahuannya tentang gizi bagi keluarga dan balita melalui berbagai media maupun dengan mengikuti penyuluhan kesehatan dan bagi petugas kesehatan agar terus meningkatkan kinerja dalam mengatasi permasalahan kesehatan terutama masalah gizi balita.

Kata kunci :faktor-faktor yang mempengaruhi, status gizi, balita

Pemerintah Indonesia merupakan salah satu negara yang menghadiri Deklarasi Milenium yang diikuti 189 negara pada bulan September 2000 di New York yang menghasilkan kesepakatan global berupaMillenium Development Goals (MDGS). Tujuan dari pembangunan tersebut terdiri dari delapan butir tujuan bersama yang mencakup pencapaian tujuan dalam beberapa bidang kehidupan untuk tercapainya kesejahteraan dan pembangunan kesehatan masyarakat pada tahun 2015. Salah satu dari tujuan tersebut yaitu menurunkan, mengurangi angka kematian anak balita ( Kemenkes, 2012 ).

Angka kematian balita merupakan salah satu indikator dari tiga indikator 
penentu derajat kesehatan di Indonesia ( WHO, 2002). Masalah kesehatan balita juga merupakan salah satu masalah utama dalam bidang kesehatan yang saat ini terjadi di Indonesia. Derajat kesehatan balita dapat mencerminkan bagaimana derajat kesehatan bangsa, sebab anak sebagai generasi penerus bangsa. Berdasarkan alasan tersebut masalah kesehatan anak diprioritaskan dalam perencanaan atau penataan pembangunan bangsa (Hidayat, 2009).

Angka kematian balita di Indonesia menempati urutan tertinggi dibandingkan Negara di ASEAN lainnya (Maryunani,A, 2010). Tingginya angka kematian balita di Indonesia disebabkan oleh berbagai faktor, yang salah satunya adalah kekurangan gizi ( Hapsari, 2004).

Masalah kekurangangizi yang sering terjadi pada balita adalah Kurang Energi Protein (KEP), Kurang Vitamin A (KVA), Gangguan Akibat Kekurangan Yodium (GAKY) dan Anemia Gizi Besi. Masalah kekurangan gizi yang terjadi tidak terlepas dari terbatasnya pengetahuan keluarga terutama ibu balita mengenai status gizi anak, pola pertumbuhan anak, nilai gizi dan makanan yang ada. Sebagian besar keluarga hanya mengetahui balita harus diberikan makanan sama halnya dengan orang dewasa tiap harinya (Depkes RI, 2004).

Balita berada pada urutan kedua dari enam kelompok yang rentan gizi. Kelompok tersebut merupakan kelompok yang mudah menderita gangguan kesehatan dan mudah mengalami kekurangan gizi. Ada salah satu hal penting yang menyebabkan balita berada dalam kelompok tersebut yaitu balita yang berada dalam masa transisi dari makanan bayi ke makanan dewasa, anak balita yang belum mampu mengurus diri sendiri termasuk dalam memilih makanan. Maka dari itu peran ibu sangat lah penting pada masa ini untuk mempertahankan pola makan yang sehat pada balita agar tidak terjadi masalah gizi (Notoatmodjo, 2003).

Masa balita disebut dengan golden period atau masa keemasan. Anak dibawah 5 tahun merupakan kelompok yang menunjukkan pertumbuhan yang pesat, bila terjadi gizi buruk pada mereka akan berpengaruh langsung pada kehidupan di usia prasekolah dan sekolah nantinya, yang akan berpengaruh pada masa depannya sehingga sangat perlu perhatian yang optimal terhadap status gizi anak pada saat itu (Arisman, 2004 ).

Menurut Robinson dan Weighley dalam buku pengantar gizi masyarakat, status gizi adalah keadaan kesehatan yang berhubungan dengan penggunaan makanan oleh tubuh. Menurutnya, status gizi dipengaruhi oleh faktor langsung yang terdiri dari pola makan dan penyakit infeksi. Pola makan yang sehat adalah suatu cara atau usaha dalam pengaturan jumlah dan jenis makanan dengan maksud tertentu, seperti mempertahankan kesehatan, status nutrisi, mencegah atau membantu kesembuhan penyakit. Faktor langsung yang menyebabkan permasalahan gizi yang kedua yaitu penyakit infeksi. Menurut Supariasa, dkk, 2001, penyakit infeksi yang umumnya terkait dengan masalah gizi antara lain, diare, TBC, ISPA, campak, batuk rejan, dan pneumonia. Hadirnya penyakit infeksi dalam tubuh anak akan membawa pengaruh terhadap gizi anak. Reaksi yang akan timbul karena adanya infeksi adalah menurunnya nafsu makan, muntah, dan mencret sehingga akan menyebebkan berkurangnya asupan makanan pada anak sehingga dengan sangat cepat mengubah tingkat gizi anak kearah gizi buruk ( Santoso, dkk, 2004).

Selain faktor langsung, status gizi balita juga di pengaruhi lima faktor tidak langsung yaitu oleh ekonomi keluarga, budaya, produksi pangan, kebersihan lingkungan dan fasilitas pelayanan kesehatan. Menurut Suhardjo 2008, yang menjadi patokan dalam ekonomi adalah kemiskinan. Kemiskinan dinilai memiliki peranan penting dan bersifat timbal balik, artinya kemiskinan akan menyebabkan kurang gizi dan individu yang kurang gizi akan melahirkan kemiskinan. Faktor tidak langsung kedua yang mempengaruhi status gizi yaitu budaya. Permasalahan yang timbul pada faktor ini karena masih ada kepercayaan untuk memantang makanan 
tertentu yang dipandang dari segi gizi sebenarnya mengandung zat gizi yang baik. Faktor ketiga yaitu fasilitas pelayanan kesehatan yang sangat penting untuk menyokong status kesehatan dan gizi anak. Faktor selanjutnya yaitu produksi pangan dan kebersihan lingkungan. Produksi pangan sebagai peranan pertanian yang penting karenan kemampuannya menghasilkan produk pangan. Sedangkan kebersihan lingkungan akan mempengaruhi kesehatan anak, kebersihan lingkungan yang buruk akan memudahkan anak menderita penyakit tertentu seperti ISPA, diare, dsb.

Menurut Adnan, M dan Wirjatmadi, B (2012), kekurangan energi protein yang akan menimbulkan masalah gizi juga dipengaruhi oleh pengetahuan gizi ibu. Seorang ibu dengan pendidikan tinggi akan dapat merencanakan menu makanan yang sehat bagi dirinya dan keluarganya dalam upaya memenuhi zat gizi yang diperlukan.

Menurut Sediaoetama, A (2006), pengetahuan gizi yang baik akan menyebabkan seseorang mampu menyusun menu yang baik untuk dikonsumsi. Semakin baik pengetahuan gizi seseorang, maka ia akan semakin memperhitungkan jenis dan jumlah makanan yang diperoleh untuk keluarga termasuk anak balita.

Salah satu provinsi di Indonesia yang memiliki masalah gizi terbanyak yaitu di NTT. Pada bulan Juli 2010, sebanyak 53.261 anak balita dari 506.352 anak balita di NTT sejak Januari hingga Juli 2010 didiagnosis menderita gizi kurang. Sementara itu, kasus gizi buruk mencapai sekitar 85 anak balita dengan kelainan klinis dan sekitar 6.157 anak balita kasus tanpa kelainan klinis.

Jumlah kasus gizi buruk yang ditemukan dan ditangani di Provinsi SumateraBarat sebanyak 764 kasus.Jumlah tinggi adalah Kabupaten Agam (229 kasus),Kabupaten Dharmasraya menempati urutan kedua setelah Kabupaten Agam yaitu sebanyak94 kasus.Menurut Data Dinas Kesehatan Sumbar, jumlah penderita gizi buruk didominasi daerah pinggiran dan pemekaran. Di Kabupaten Dharmasraya terdapat sekitar 3 persen balita gizi burukdari 473.804 jumlah Balita di Sumbar.

Berdasarkan penelitian Zulkarnain Agus (2012), kasus gizi cukup tinggi di daerah pinggiran seperti Dharmasraya.Hal ini dapat terjadi karena rendahnya akses masyarakat terhadap kesehatan.Dharmasraya merupakan daerah otonomi yang mana dalam sistem pemerintahan Indonesia, untuk menentukan nasib derajat kesehatan bangsa atau the real battle untuk memperjuangkan derajat kesehatan masyarakat adalah ditingkat wilayah otonom yang dewasa ini ada di tingkat Kabupaten dan Wilayah Kota.Ketetapan MPR XV/MPR/1998 tentang penyelenggaraan Otonomi Daerah dan UU no 22 tahun 1999 tentang Pemerintahan daerah telah diberlakukan dan dijadikan pedoman penyelenggaraan pemerintah bidang kesehatan sehingga diharapkan pelayanan kesehatan dapat dinikmati oleh seluruh masyarakat.

Berdasarkan data dari dinas kesehatan kabupaten Dharmasraya tahun 2011, jumlah balita di kabupaten Dharmasraya yang tercatat yaitu sebanyak 19.606 balita. Kabupaten Dharmasraya terdiri dari 11 kecamatan yang salah satunya yaitu kecamatan Koto Besar dengan persentase tertinggi jumlah balita yang menderita gizi buruk yaitu sebanyak 4,6 persen (diukur menurut bb/tb) dari jumlah balita 2.343 balita. Dari 5 nagari yang terdapat di kecamatan Koto Besar, nagari Abai Siat merupakan nagari yang memiliki balita terbanyak yang mengalami gizi buruk yaitu 2,6\% dari 386 jumlah balita.

Dari studi awal yang dilakukan pada bulan september 2012 kepada 2 orang petugas kesehatan dipuskesmas terkait, menurutnya masalah gizi yang terjadi di kecamatan tersebut di sebabkan oleh beberapa hal yaitu, rendahnya pengetahuan ibu terhadap status gizi anak dan pengetahuan terhadap zat gizi lengkap yang harus di berikan kepada anak setiap makan, Sedangkan studi awal yang dilakukan kepada ibu yang mempunyai balita dari 8 orang ibu tersebut 5 orang ibu tidak mengetahui apa saja yang diperlukan untuk gizi balita, dan 
tidak tahu apa saja penyakit infeksi yang bisa terjadi pada balita, ibu tersebut mengatakan tidak mengetahui tentang apa saja makanan yang bergizi buat balita, dan mereka banyak mengeluhkan bahan makanan yang bergizi untuk balita tersebut mahal, sedangkan pendapatan mereka dalam satu bulan hanya cukup untuk keperluan sehari-hari saja, jadi penyebab yang kedua yaitu status ekonomi masyarakat. Halini nantinya akan berpengaruh kepada asupan makanan dan pola makan dalam keluarga. Ibu balita juga mengatakan sering membawa anak mereka ke dukun apabila anak mereka sakit. Masih kentalnya unsur budaya didaerah setempat yang masih mempercayai dukun sebagai alternatif pengobatan balita mereka apabila sakit hal ini nantinya juga akan menentukan keberhasilan pelayanan kesehatan di daerah tersebut dalam menjalankan programprogram untuk meningkatkan taraf kesehatan balita dan mencegah timbulnya gizi buruk pada balita didaerah tersebut. Dari data yang didapatkan dari puskesmas penyakit yang banyak diderita balita selama 6 bulan terakhir yaitu diantaranya ISPA, infeksi paru dan infeksi saluran pencernaan.

Berdasarkan fenomena di ataspenulis tertarik melakukan penelitian dengan judul" Faktor-faktor yang berhubungan dengan Status Gizi pada Balita Di Nagari Abai Siat Wilayah Kerja Puskesmas Koto Besar Kabupaten Dharmasraya Tahun 2013”.

\section{METODE}

Penelitian ini bersifat analitik dengan menggunakan pendekatan cross sectional study.Populasi pada penelitian ini adalah semua ibu balita di Nagari Abai Siat Wilayah Kerja Puskesmas Koto Besar Kabupaten Dharmasraya Tahun 2013, yaitu sebanyak 386 orang.Teknik yang digunakan dalam pengambilan sampel adalah propotional random sampling.Jumlah sampeldalam penelitian ini adalah sebanyak 196 balita.

\section{HASIL DAN PEMBAHASAN}

Penelitian ini dilakukan kepada ibu-ibu yang memiliki anak balita yang ada di Nagari Abai Siat Wilayah Kerja Puskesmas Koto Besar Kabupaten Dharmasraya. Pengumpulan data dilakukan pada tanggal 1 - 20 April 2013. Pengumpulan data diambil dengan memberikan kusioner yang terdiri dari 28 pertanyaan kepada ibu-ibu balita di Posyandu Permata Indah sebanyak 55 orang, Posyandu Bungur Indah sebanyak 84 orang, dan Posyandu Kasih Ibu sebanyak 57 orang dengan jumlah total sebanyalk 196 orang responden. Pengambilan data dilakukan di masing-masing posyandu dan dirumah ibuibu balita. Hasil penelitian ini disajikan dalam dua bentuk yaitu tabel distribusi frekuensi dan narasi.

Tabel 1.Distribusi Frekuensi Responden Menurut Status Gizi Balita di Nagari Abai Siat Wilayah Kerja Puskesmas Koto Besar Kabupaten Dharmasraya Tahun 2013

\begin{tabular}{|c|c|c|}
\hline Status Gizi & Frekuensi & Persentase \\
\hline Baik & 95 & 48,5 \\
\hline Kurang & 99 & 50,5 \\
\hline Buruk & 2 & 1,0 \\
\hline Jumlah & 196 & 100 \\
\hline
\end{tabular}

Balita dengan $\mathrm{bb} / \mathrm{u}$ berada dibawah garis merah dilihat dari kms, balita sudah mengalami penambahan berat badan pada beberapa bulan terakhir dan sudah ditangani oleh oleh petugas pelayanan kesehatan dengan pemberian BMT.

Penelitian ini menunjukkan bahwa sebagian besar responden dengan balita gizi kurang banyak berkisar pada umur balita 1-3 
tahun yaitu sebanyak 56 orang $(56,6 \%)$ dibandingkan dengan balita pada usia 4-5 tahun yaitu sebanyak 39 orang responden $(39,4 \%)$. status gizi anak pada usia ini sebagian besar sangat ditentukan oleh pola makan anak yang diberikan ibunya dan pengetahuan ibu dalam menyusun menu makanan tersebut.

Tabel 2.Distribusi Frekuensi Responden Menurut Pola MakanBalita diAbai Siat Wilayah Kerja Puskesmas Koto Besar Kabupaten Dharmasraya Tahun 2013

\begin{tabular}{|c|c|c|}
\hline Pola makan & Frekuensi & Persentase \\
\hline Baik & 105 & 53,6 \\
\hline Kurang & 91 & 46,4 \\
\hline Jumlah & 196 & 100 \\
\hline
\end{tabular}

Balita yang mempunyai pola makan yang kurang baik disebabkan karena ibu balita yang cenderung menuruti kemauan anak dalam memberikan makanan walaupun makanan yang diberikan tidak bergizi, yang kedua yaitu karena ibu balita sering memberikan makanan dengan kandungan gula yang berlebihan dan yang terakhir karena ibu balita membiarkan balitanya untuk menentukan sendiri seberapa banyak makanan yang dikonsumsi tanpa memperhatikan jumlah makanan yang baik yang harus dikonsumsi balitanya

Tabel 3.Distribusi Frekuensi Responden Menurut Tingkat Pengetahuan Ibudi Abai SiatWilayah Kerja Puskesmas Koto Besar Kabupaten DharmasrayaTahun 2013

\begin{tabular}{|c|c|c|}
\hline Tingkat Pengetahuan & Frekuensi & Persentase \\
\hline Baik & 93 & 47,4 \\
\hline Kurang & 103 & 53,6 \\
\hline Jumlah & 196 & 100 \\
\hline
\end{tabular}

Hal ini dapat di tunjang oleh latar belakang pendidikan responden yang sebagian besar SMP $(35,7 \%)$ dan SD $(32,7 \%)$. Tingkat pendidikan akan mempengaruhi seseorang dalam menerima informasi yang diberikan terutama ibu balita tentang informasi mengenai kesehatan balita. Sebagian besar responden memiliki pengetahuan yang kurang tentang status gizi balita, makanan yang harus dikonsumsi balita yang mana responden lebih memberikan makanan kepada balita tergantung keinginan balita dan tergantung makanan yang tersedia dirumah tanpa mengetahui kalau makanan yang harus di konsumsi harus beragam jenisnya dan responden juga memiliki pengetahuan yang kurang tentang jumlah dan porsi yang cukup untuk balita. 
Tabel 4.Distribusi Frekuensi Responden Menurut Penyakit Infeksi

Balita diAbai SiatWilayah Kerja Puskesmas Koto Besar Kabupaten

DharmasrayaTahun2013

\begin{tabular}{|c|c|c|}
\hline Penyakit Infeksi & Frekuensi & Persentase \\
\hline Tidak Sakit & 54 & 27,6 \\
\hline Sakit & 142 & 72,4 \\
\hline Jumlah & 196 & 100 \\
\hline
\end{tabular}

Hasil penelitian menunjukkan bahwa 142 balita $(72,4 \%)$ mengalami sakit dan 54 balita $(27,6 \%)$ tidak mengalami sakit

Penyakit infeksi yang diderita balita di Kenagarian Abai Siat yaitu diantaranya : diare, TBC, ISPA, campak, batuk rejan, pneumonia.

Hadirnya penyakit infeksi dalam tubuh anak membawa pengaruh terhadap keadaan gizi anak dan akan memperburuk keadaan gizi. Reaksi yang akan timbul karena adanya infeksi adalah menurunnya nafsu makan, muntah, dan mencret sehingga akan menyebebkan berkurangnya asupan makanan pada anak sehingga dengan sangat cepat mengubah tingkat gizi anak kearah gizi buruk.

Tabel 5.Distribusi Frekuensi Responden Menurut Status Ekonomi Keluarga Balita di Nagari Abai Siat Wilayah Kerja Puskesmas Koto Besar Kabupaten Dharmasraya Tahun 2013

\begin{tabular}{|c|c|c|}
\hline Status Ekonomi & Frekuensi & Persentase \\
\hline Mampu & 126 & 64,3 \\
\hline Kurang Mampu & 70 & 35,7 \\
\hline Jumlah & 196 & 100 \\
\hline
\end{tabular}

hasil penelitian menunjukkan bahwa 126 orang responden $(64,3 \%)$ dengan status ekonomi mampu dan 70 responden $(35,7 \%)$ dengan status ekonomi kurang mampu.

Penelitian ini menunjukkan bahwa sebagian besar responden mempunyai status ekonomi mampu, hal ini diduga dikarenakan pekerjaan responden pada umumnya yaitu berkebun dan bertani yang umumnya memiliki lahan sendiri dengan pendapatan rata-rata sebesar Rp.1.500.000Rp.2.500.000per bulannya. Status ekonomi tersebut nantinya akan berpengaruh dalam pemenuhan kebutuhan, serta tersedianya jaminan ekonomi dalam melakukan pembiayaan pengobatan dalam keluarga tersebut, sehingga diharapkan nantinya akan berdampak baik terhadap status gizi balita dalam keluargatersebut. 
Tabel 6.Distribusi Frekuensi Responden Menurut Pelayanan Kesehatan di Nagari Abai Siat Wilayah Kerja Puskesmas Koto Besar Kabupaten DharmasrayaTahun 2013

\begin{tabular}{|c|c|c|}
\hline Pelayanan Kesehatan & Frekuensi & Persentase \\
\hline Baik & 191 & 97,4 \\
\hline Kurang & 5 & 2,6 \\
\hline Jumlah & 196 & 100 \\
\hline
\end{tabular}

Sebagian besar responden mengatakan bahwa pelayanan kesehatan dan informasi yang diberikan oleh petugas kesehatan di Nagari Abai Siat sudah baik, hal ini dapat dilihat dari kusioner, seluruh responden menjawab bahwa seluruh responden pernah memanfaatkan fasilitas kesehatan yang ada di Kenagarian Abai Siat Wilayah Kerja Puskesmas Koto Besar dan seluruh responden mengatakan bahwa pelayanan kesehatan yang diberikan baik.

Tabel 7.Distribusi Frekuensi Responden Menurut Budaya Ibu Balita di Nagari Abai Siat Wilayah Kerja Puskesmas Koto Kabupaten Dharmasraya

Tahun 2013

\begin{tabular}{|c|c|c|}
\hline Budaya & Frekuensi & Persentase \\
\hline Baik & 138 & 70,4 \\
\hline Kurang & 58 & 29,6 \\
\hline Jumlah & 196 & 100 \\
\hline
\end{tabular}

hasil penelitian dapat dilihat bahwa masih ada sebagian kecil responden sekitar 29,6\% masih memantangkan makanan seperti sayur-sayuran, buah dan makanan bergizi lainnya terhadap balitanya dan responden juga masih mempercayai solusi pengobatan seperti ke dukun apabila balitanya mengalami sakit.

Tabel 8.Distribusi Frekuensi Responden Menurut pola makan terhadap status gizi balita di Nagari Abai Siat Wilayah Kerja Puskesmas Koto Besar Kabupaten Dharmasraya Tahun 2013

\begin{tabular}{|c|c|c|c|c|c|c|c|c|}
\hline \multirow{3}{*}{$\begin{array}{c}\text { Pola } \\
\text { makan }\end{array}$} & \multicolumn{6}{|c|}{ Status Gizi } & \multicolumn{2}{|c|}{} \\
\cline { 2 - 10 } & \multicolumn{2}{|c|}{ Baik } & \multicolumn{2}{c|}{ Kurang } & \multicolumn{2}{c|}{ Buruk } & \multicolumn{2}{c|}{ Total } \\
\cline { 2 - 10 } & $\mathrm{f}$ & $\%$ & $\mathrm{f}$ & $\%$ & $\mathrm{f}$ & $\%$ & $\mathrm{f}$ & $\%$ \\
\hline Baik & 83 & 79 & 21 & 20 & 1 & 1,1 & 105 & 53,6 \\
\hline Kurang & 12 & 13,2 & 78 & 85,7 & 1 & 1 & 91 & 46,4 \\
\hline Jumlah & $\mathbf{9 5}$ & $\mathbf{9 2 , 2}$ & $\mathbf{9 9}$ & $\mathbf{1 0 5 , 7}$ & $\mathbf{2}$ & $\mathbf{2 , 1}$ & $\mathbf{1 9 6}$ & $\mathbf{1 0 0}$ \\
\hline
\end{tabular}

Hasil penelitian ini didapatkan bahwa adanya hubungan pola makan dengan status gizi balita dengan $p$ value $0,000<0,05$. Artinya semakin baik pola makan semakin baik pula status gizi balita tersebut dan sebaliknya semakin buruk pola makan semakin buruk pula status gizi balita tersebut. Hasil penelitian ini menunjukkan bahwa sebagian besar responden balitanya memiliki pola makan yang baik dan sebaliknya sebagian dari responden juga ada balitanya dengan pola makan yang kurang hal ini disebabkan karena ibu cenderung membiarkan balitanya untuk memilih sendiri makanan yang akan dikonsumsi walaupun makanan tersebut tidak bergizi, ibu juga sering memberikan 
makanan bergula yang berlebihan kepada balita dan ibu juga sering membiarkan balita untuk menentukan sendiri jumlah makanan yang akan dikonsumsi setiap harinya tanpa memperhatikan jumlah yang baik yang telah ditentukan. Sebagian responden yang balitanya memiliki pola makan yang baik masih ada balitanya dengan status gizi kurang dan buruk. Hal tersebut diduga dapat disebabkan oleh karena bukan pola makan saja yang dapat mempengaruhi status gizi tapi ada hal lain seperti : penyakit infeksi yang diderita balita, pengetahuan ibu, status ekonomi dan budaya.

Tabel 9.Distribusi Frekuensi Responden Menurut tingkat pengetahuan ibu terhadap status gizi balita di Nagari Abai Siat Wilayah

Kerja Puskesmas Koto Besar Kabupaten Dharmasraya Tahun 2013

\begin{tabular}{|c|c|c|c|c|c|c|c|c|}
\hline \multirow{3}{*}{$\begin{array}{l}\text { Tingkat } \\
\text { Pengetahuan }\end{array}$} & \multicolumn{6}{|c|}{ Status Gizi } & \multirow{2}{*}{\multicolumn{2}{|c|}{ Total }} \\
\hline & \multicolumn{2}{|c|}{ Baik } & \multicolumn{2}{|c|}{ Kurang } & \multicolumn{2}{|c|}{ Buruk } & & \\
\hline & $\mathrm{f}$ & $\%$ & $f$ & $\%$ & $\mathrm{f}$ & $\%$ & $\mathrm{~F}$ & $\%$ \\
\hline Baik & 81 & 87,1 & 12 & 12,9 & 0 & 0 & 93 & 47,4 \\
\hline Kurang & 14 & 13,6 & 87 & 84,5 & 2 & 1,9 & 103 & 52,6 \\
\hline Jumlah & 95 & 100,7 & 99 & 97,4 & 2 & 1,9 & 196 & 100 \\
\hline
\end{tabular}

Hasil penelitian ini didapatkan bahwa adanya hubungan tingkat pengetahuan ibu dengan status gizi balita dengan pvalue $0,000<0,05$. Artinya semakian baik pengetahuan gizi ibu maka status gizi balitanya semakin baik pula dan sebaliknya, semakin kurang pengetahuan ibu maka status gizi balitanya semakin buruk pula. Pada penelitian ini dapat dilihat bahwa responden memiliki pengetahuan yang kurang tentang status gizi balita, makanan yang harus dikonsumsi balita yang mana responden lebih memberikan makanan kepada balita tergantung keinginan balita dan tergantung makanan yang tersedia dirumah tanpa mengetahui kalau makanan yang harus di konsumsi harus beragam jenisnya dan responden juga memiliki pengetahuan yang kurang tentang jumlah dan porsi yang cukup untuk balita. Hal tersebut nantinya akan berdampak buruk terhadap status gizi balita karena Pengetahuan ibu tentang gizi yang cukup akan membantu ibu khususnya dalam hal pemenuhan zat-zat gizi dalam penyediaan makanan sehari-hari, karena dengan hal itu ibu akan mengetahui pola pemberian makanan yang memiliki gizi kepada balita maupun keluargasehingga pemenuhan gizi bagi keluarga akan terjadi dan dengan hal ini akan membuat kecukupan gizi bagi balita dan keluarga akan terpenuhi.

Tabel 10.Distribusi Frekuensi Responden Menurut Penyakit Infeksi terhadap Status Gizi Balita di Nagari Abai Siat WilayahKerja Puskesmas Koto Besar Kabupaten DharmasrayaTahun 2013

\begin{tabular}{|c|c|c|c|c|c|c|c|c|}
\hline \multirow{2}{*}{$\begin{array}{l}\text { Penyakit } \\
\text { Infeksi }\end{array}$} & \multicolumn{6}{|c|}{ Status Gizi } & \multirow{2}{*}{ Total } \\
\cline { 2 - 9 } & B & $\%$ & f & $\%$ & f & $\%$ & F & $\%$ \\
\hline Tdk Sakit & 46 & 85,2 & 8 & 14,8 & 0 & 0 & 54 & 27,6 \\
\hline Sakit & 49 & 34,5 & 91 & 64,1 & 2 & 1,4 & 142 & 72,4 \\
\hline Jumlah & $\mathbf{9 5}$ & $\mathbf{1 1 9 , 7}$ & $\mathbf{9 9}$ & $\mathbf{7 8 , 9}$ & $\mathbf{2}$ & $\mathbf{1 , 4}$ & $\mathbf{1 9 6}$ & $\mathbf{1 0 0}$ \\
\hline
\end{tabular}


Hasil penelitian ini didapatkan bahwa adanya hubungan penyakit infeksi dengan status gizi balita dengan $p$ value $0,000<0,05$. Artinya hadirnya penyakit infeksi akan menyebabkan status gizi balita semakinburuk. penyakit infeksi dalam tubuh anak membawa pengaruh terhadap keadaan gizi anak dan akan memperburuk keadaan gizi. Penyakit infeksi yang umumnya terkait dengan masalah gizi antara lain diare, TBC, ISPA, campak, batuk rejan, pneumonia. reaksi yang akan timbul karena adanya infeksi adalah menurunnya nafsu makan, muntah, dan mencret sehingga akan menyebebkan berkurangnya asupan makanan pada anak sehingga dengan sangat cepat mengubah tingkat gizi anak kearah gizi buruk.

Jenis penyakit infeksi yang diderita balita dalam penelitian ini diantaranya: demam, batuk, pilek,sesak nafas, diare, campak, TBC dan radang paru-paru. Balita yang mengalami sakit dapat disebabkan karena perubahan cuaca sehingga mempengaruhi kondisi kesehatan, daya tahan tubuh yang menurun dan kebersihan lingkungan.

Tabel 11.Distribusi Frekuensi Responden Menurut status ekonomi terhadap Status Gizi Balita di Nagari Abai Siat Wilayah Kerja Puskesmas Koto Besar Kabupaten Dharmasraya Tahun 2013

\begin{tabular}{|c|c|c|c|c|c|c|c|c|}
\hline \multirow{2}{*}{$\begin{array}{l}\text { Status } \\
\text { Ekonomi }\end{array}$} & \multicolumn{9}{|c|}{ Status Gizi } & \multicolumn{2}{c|}{} \\
\cline { 2 - 9 } & \multicolumn{2}{|c|}{ Baik } & \multicolumn{2}{c|}{ Kurang } & \multicolumn{2}{c|}{ Buruk } & \multicolumn{2}{c|}{ Total } \\
\cline { 2 - 9 } & $\mathrm{f}$ & $\%$ & $\mathrm{f}$ & $\%$ & $\mathrm{f}$ & $\%$ & $\mathrm{f}$ & $\%$ \\
\hline Mampu & 81 & 64,3 & 44 & 35,2 & 1 & 0,8 & 126 & 64,3 \\
\hline KrgMampu & 14 & 20 & 55 & 78,6 & 1 & 1,4 & 70 & 35,7 \\
\hline Jumlah & $\mathbf{9 5}$ & $\mathbf{8 4 , 3}$ & $\mathbf{9 9}$ & $\mathbf{1 1 3 , 8}$ & $\mathbf{2}$ & $\mathbf{2 , 2}$ & $\mathbf{1 9 6}$ & $\mathbf{1 0 0}$ \\
\hline
\end{tabular}

Hasil penelitian menunjukkan bahwa sebagian besar responden memiliki status ekonomi yang mampu hal ini di duga disebabkan oleh karena sebagian besar responden berpenghasilan dari berkebun dan bertani yang umumnya sudah memiliki lahan sendiri dengan pendapatan berkisar Rp.1.500.000-Rp.2.500.000 per bulannya. Hasil penelitian juga menunjukkan bahwa adanya hubungan status ekonomi dengan status gizi balita dengan $p$ value

$0,000<0,05$. Artinya semakin baik status ekonomi keluarga maka semakin baik pula status gizi balita dalam keluarga tersebut, dan sebaliknya. Status ekonomiakan mempengaruhi sikap seseorang dalam penggunaan pelayanan kesehatan dan dapat mempertahankan tingkat keteraturan dalam penggunaan pelayanan kesehatan.

Dari hasil penelitian juga terdapat responden yang status ekonominya mampu tetapi balitanya berstatus gizi kurang dan buruk.Hal disebabkan karena, faktor lain seperti balita yangpola makan yang salah, kurangnya pengetahuan ibu tentang gizi, serta balita menderita penyakit infeksi. 
Tabel 12.Distribusi Frekuensi Responden Menurut pelayanan kesehatan terhadap Status Gizi Balita di Nagari Abai Siat Wilayah Kerja

Puskesmas Koto Besar Kabupaten DharmasrayaTahun 2013

\begin{tabular}{|c|c|c|c|c|c|c|c|c|}
\hline \multirow{2}{*}{$\begin{array}{c}\text { Pelayanan } \\
\text { Kesehatan }\end{array}$} & \multicolumn{7}{|c|}{ Status Gizi } & \multicolumn{2}{|c|}{} \\
\cline { 2 - 9 } & \multicolumn{2}{|c|}{ Baik } & \multicolumn{2}{c|}{ Kurang } & \multicolumn{2}{c|}{ Buruk } & \multicolumn{2}{c|}{ Total } \\
\cline { 2 - 9 } & $\mathrm{f}$ & $\%$ & $\mathrm{f}$ & $\%$ & $\mathrm{f}$ & $\%$ & $\mathrm{f}$ & $\%$ \\
\hline Baik & 93 & 48,7 & 96 & 50,3 & 2 & 1 & 191 & 97,4 \\
\hline Kurang & 2 & 40 & 3 & 60 & 0 & 0 & 5 & 2,6 \\
\hline Jumlah & $\mathbf{9 5}$ & $\mathbf{8 8 , 7}$ & $\mathbf{9 9}$ & $\mathbf{5 6 , 3}$ & $\mathbf{2}$ & $\mathbf{1}$ & $\mathbf{1 9 6}$ & $\mathbf{1 0 0}$ \\
\hline
\end{tabular}

Hasil penelitian ini didapatkan bahwa tidak adanya hubungan pelayanan kesehatan dengan status gizi balita dengan pvalue $0,874>0,05$. Artinya walaupun pelayanan kesehatan sudah memberikan pelayanan dan informasi yang baik tentang kesehatan balita belum tentu status gizi balita di daerah tersebut cukup baik.

Tabel 13.Distribusi Frekuensi Responden Menurut budaya terhadap Status Gizi Balita di Nagari Abai Siat Wilayah Kerja Puskesmas Koto Besar Kabupaten Dharmasraya Tahun 2013

\begin{tabular}{|c|c|c|c|c|c|c|c|c|}
\hline \multirow{3}{*}{ Budaya } & \multicolumn{7}{|c|}{ Status Gizi } & \multicolumn{2}{c|}{} \\
\cline { 2 - 9 } & \multicolumn{2}{|c|}{ Baik } & \multicolumn{2}{|c|}{ Kurang } & \multicolumn{2}{c|}{ Buruk } & \multicolumn{2}{c|}{ Total } \\
\cline { 2 - 9 } & $\mathrm{f}$ & $\%$ & $\mathrm{f}$ & $\%$ & $\mathrm{~F}$ & $\%$ & $\mathrm{f}$ & $\%$ \\
\hline Baik & 81 & 58,7 & 55 & 39,9 & 2 & 1,4 & 138 & 70,4 \\
\hline Kurang & 14 & 24,1 & 44 & 75,9 & 0 & 0 & 58 & 29,6 \\
\hline Jumlah & $\mathbf{9 5}$ & $\mathbf{8 2 , 8}$ & $\mathbf{9 9}$ & $\mathbf{1 1 5 , 8}$ & $\mathbf{2}$ & $\mathbf{1 , 4}$ & $\mathbf{1 9 6}$ & $\mathbf{1 0 0}$ \\
\hline
\end{tabular}

Hasil penelitian ini didapatkan bahwa adanya hubungan budaya dengan status gizi balita dengan $p$ value $0,000<0,05$. Artinya, semakin baik budaya yang ada dalam suatu keluarga mengenai kesehatan, maka semakin baik pula status gizi balita dalam keluarga tersebut.Hasil penelitian menunjukkan bahwa sebagian besar responden sudah memiliki budaya yang baik dalam keluarga mengenai kesehatan balitanya. Namun, masih ada sebagian kecil responden yang memiliki budaya yang kurang baik seperti masih adanya kepercayaan responden terhadap dukun untuk pengobatan balitanya

\section{KESIMPULAN DAN SARAN}

Berdasarkanhasil penelitian yang dilakukan dapat disimpulkan:Lebih dari separoh balita yang sakit dan masih adanya pantangan terhadap makanan yang bergizi sepe 5 ttrti pantangan terhadap buah-buahan dan sayursayuran.

Responden yang memiliki budaya yang cukup baik mengenai status gizi balitanya namun balitanya dengan status gizi kurang. Hal ini diduga disebabkan karena faktor yang mempengaruhi status gizi bukan hanya budaya saja namun masih banyak faktor yang lain seperti: pola makan yang salah, kurangnya pengetahuan ibu tentang gizi, serta balita menderita penyakit infeksi.

di Nagari Abai Siat Wilayah Kerja Puskesmas Koto Besar Kabupaten Dharmasraya Tahun 2013 memiliki status gizi yang kurang $(50,5 \%)$, memiliki pola makan yang baik $(53,6 \%)$ dan $72,4 \%$ balita 
mengalami penyakit infeksi selama 3 bulan terakhir, lebih dari separoh responden di Nagari Abai Siat Wilayah Kerja Puskesmas Koto Besar Kabupaten Dharmasraya Tahun 2013 memiliki pengetahuan gizi yang kurang $(53,6 \%)$, sebanyak $64,3 \%$ responden dengan status ekonomi mampu, sebanyak 97,4\% responden mengatakan bahwa pelayanan kesehatan di Abai Siat sudah memberikan pelayanan yang baik dan sebanyak 70,9\% responden memiliki budaya yang baik terkait kesehatan balita, terdapat hubungan yang bermakna antara pola makan dengan status gizi balita di Nagari Abai Siat Wilayah Kerja Puskesmas Koto Besar Kabupaten Dharmasraya Tahun 2013, terdapat hubungan yang bermakna antara Tingkat Pengetahuan Ibu dengan status gizi balita di Nagari Abai Siat Wilayah Kerja Puskesmas Koto Besar Kabupaten Dharmasraya Tahun 2013, terdapat hubungan yang bermakna antara penyakit infeksi dengan status gizi balita di Nagari Abai Siat Wilayah Kerja Puskesmas Koto Besar Kabupaten Dharmasraya Tahun 2013, terdapat hubungan yang bermakna antara status ekonomi dengan status gizi balita di Nagari Abai Siat Wilayah Kerja Puskesmas Koto Besar Kabupaten Dharmasraya Tahun 2013, tidak ada hubungan yang bermakna antara pelayanan kesehatan dengan status gizi balita di Nagari Abai Siat Wilayah Kerja Puskesmas Koto Besar Kabupaten Dharmasraya Tahun 2013, terdapat hubungan yang bermakna antara budaya dengan status gizi balita di Nagari Abai Siat Wilayah Kerja Puskesmas Koto Besar Kabupaten Dharmasraya Tahun 2013. dari hasil penelitian disarankan agar : ibu-ibu balita yang ada di Wilayah Kerja Puskesmas Koto Besar agar senantiasa meningkatkan pengetahuannya tentang gizi bagi keluarga dan balita melalui berbagai media maupun dengan mengikuti penyuluhan kesehatan tentang gizi oleh tenaga kesehatan agar menambah pengetahuan dalam hal pemenuhan gizi keluarga dan balita, dan kepada petugas kesehatan yang ada di Wilayah Kerja Puskesmas Koto Besar agar terus meningkatkan kinerja dalam mengatasi permasalahan kesehatan terutama masalah gizi balita di Wilayah Kerja Puskesmas Koto Besar. Petugas kesehatan juga dapat meningkatkan upaya peningkatan status gizi balita seperti : kunjungan rumah, monitoring dan memastikan dalam pemberian makanan tambahan

\section{DAFTAR PUSTAKA}

Achmadi, U, F. (2008). Horison Baru Kesehatan Masyarakat di Indonesia.

Jakarta: Rineka Cipta

Adriani, M dan Bambang, W. ( 2012).

Pengantar Gizi Masyarakat. Jakarta:

Kencana

Almatsier, A. (2004). Prinsip Dasar Ilmu

Gizi. Jakarta: Gramedia Pustaka Utama

Arisman. (2004). Gizi Dalam Daur

Kehidupan. Jakarta: EGC

Arisman. (2009). Gizi Dalam Daur

Kehidupan. Jakarta: EGC

Data Puskesmas Koto Besar. (2011) .

Statistik Balita Kecamatan Koto Besar dan

Balita Gizi Buruk 2011

Departemen Kesehatan RI. (2011). Statistik

Provinsi dengan Gizi Buruk 2011.

Diakses tanggal 12 September 2012

dari http://www.kompas.com

Devi, S. (2011). Faktor-faktor yang mempengaruhi status gizi balita di

Kenagarian Gantung Wilayah Kerja

Puskesmas Selayo Kabupaten

SolokTahun 2011. Skripsi yang tidak diterbitkan Poltekes. Padang

Dinas Kesehatan Kabupaten Dharmasraya (2011). Statisik Balita Gizi Buruk 2011

Dinas Kesehatan Provinsi Sumatera Barat. (2011). Tajuk Atasi Gizi Buruk 2011.

Diakses pada tanggal 12 September

2012 dari harian

$$
\text { singgalang.co.id/atasigiziburuk }
$$

Dinas Tenaga Kerja Sumbar. (2012). Standar UMR untuk Sumbar. Diakses

tanggal 4 Februari 2013 dari: www.gajimu.com/gaji/GajiMinimumdan UMP-2012) 
Djaeni, A. (2006). Ilmu Gizi I. Jakarta: Dian Rakyat

Gagne. (2002). Diambil dari penelitian Yuliani Tahun 2011. Skripsi:

Minang. Padang

tidak diterbitkan Stikes Ranah

Hidayat, A.(2007). Riset Keperawatan dan Teknik Penulisan Ilmiah. Jakarta: Salemba Medika

Hidayat, A.(2009).Ilmu Kesehatan Anak.Jakarta: Salemba Medika

Hiryani, D. (2012). Pengaruh Pelayanan Kesehatan terhadap Gizi Buruk Anak Usia6 - 24 Bulan. Skripsi yang tidak diterbitkan Universitas Jenderal Soedirman Purwokerto

Jumilia. (2011). Hubungan Perilaku Pengasuh dan Sosial Budaya dalam pemberian makanan dengan status gizi batita di tinjau dari $B B / T B$ di Kelurahan Padang Besi Puskesmas Lubuk Kilangan Padang 2011. Skripsi yang tidak diterbitkan Universitas Andalas. Padang

Kemenkes RI. (2012). Laporan Pencapaian MDGs Indonesia. Jakarta

Kus, I, dkk. (2004). Gizi dan Pola Hidup Sehat. Bandung: Yrama Widya

Manjilala. (2007). Faktor-faktor yang mempengaruhi status gizi balita di Wilayah

Kerja Puskesmas Mamajang Tahun 2007. Skripsi yang tidak diterbitkan

Universitas Haluoleo. Kendari

Maryunani, A. (2010).Pengantar Gizi Masyarakat.Jakarta: Kencana

Notoatmodjo, S. (2003). Prinsip-prinsip Dasar Ilmu Kesehatan Masyarakat.

Jakarta: Rineka Cipta

Notoatmodjo, S. (2005). Metodologi Penelitian Kesehatan. Jakarta: Rineka Cipta

Notoatmodjo, S. (2010). Metodologi Penelitian Kesehatan. Jakarta: Rineka Cipta Proverawati, A dan Wati, E, k. (2011). Ilmu Gizi untuk Keperawatan dan Gizi
Medika

Kesehatan. Yogyakarta: Nuha

Robinson dan Weighley. (2012). Pengantar

Gizi Masyarakat. Jakarta: Kencana

Prenada Media

Rusepno. (2002). Ilmu Kesehatan Anak. Jakarta: FKUI

Santoso, L. (2004). Kesehatan dan Gizi. Jakarta: Rineka Cipta

Suhardjo. (2001). Perencanaan pangan dan gizi. Jakarta: Bumi Aksara

Supariasa, dkk. (2001). Penilaian Status Gizi. Jakarta: EGC

Unicef . (1999). Masalah Gizi Buruk.

Diakses pada tanggal 12 September 2012

dari http://bappeda. Jabarprov.go.id

Universitas Andalas. (2012). Pedoman

Penulisan Skripsi Fakultas Keperawatan

WHO. (2002). Ilmu Kesehatan Anak. Jakarta: EGC

Yulius. (2008).faktor risiko kejadian gizi buruk pada balita di wilayah kerja

Puskesmas Mata Kota Kendari

Tahun 2008. Skripsi yang tidak diterbitkan

Universitas Haluoleo. Kendari 